\title{
Environmental enrichment reduces brain excitability in adult rats overnourished during lactation
}

\author{
Enriquecimento ambiental reduz excitabilidade cerebral em ratos adultos hipernutridos \\ durante a lactação
}

Danielle Viana de Souza ALVES ${ }^{1}$, Mariana Séfora Bezerra SOUSA', Maryane Gabriela TAVARES', Luis Gustavo Carvalho dos SANTOS², Manuella BATISTA-DE-OLIVEIRA-HORNSBY', Angela

AMANCIO-DOS-SANTOS²

\begin{abstract}
Objective: This study aimed to analyze whether exposure to environmental enrichment (EE) during the juvenile phase of life interferes with the electrical activity of the adult rat brain. In addition, the present research also investigated whether this putative effect on brain electrical activity could be affected by prior overnutrition during lactation. Electrophysiology was measured through cortical spreading depression (CSD), a phenomenon related to brain excitability. Methods: Wistar rats were suckled in litters of either nine or three pups, forming the nourished (N) or overnourished (ON) groups, respectively. At 36 days old, half of the animals from each nutritional condition were exposed to EE. The other half was kept in the standard environment (SE). At 90-120 days of life, each animal was anesthetized for CSD recordings. Results: Overnutrition during lactation caused increases $(p<0.05)$ in body and brain weights. The EE decelerated CSD propagation velocity regardless of nutritional state during lactation $(p<0.001)$. The CSD deceleration in the N-EE group was $23.8 \%$ and in the ON-EE group was $15 \%$ in comparison with the N-SE and ON-SE groups, respectively. Conclusion: Our data demonstrated that EE exposure in the juvenile phase of the rat's life reduced brain excitability, and this effect was observed even if animals were overnourished during lactation. An EE could be considered an adjuvant therapeutic resource to modulate brain excitability.
\end{abstract}

Keywords: Cortical spreading depression; electrophysiology; rats.

\section{RESUMO}

Objetivo: Este estudo analisou se a exposição ao ambiente enriquecido durante a fase juvenil da vida interferiria na atividade elétrica do cérebro de ratos adultos. Além disso, a presente pesquisa também investigou se esse provável efeito na atividade elétrica cerebral poderia ser afetado pela hipernutrição durante a lactação. A eletrofisiologia foi medida através da depressão alastrante cortical, um fenômeno relacionado à excitabilidade cerebral. Métodos: Ratos Wistar foram amamentados em ninhadas de nove ou três filhotes, formando os grupos nutridos ou hipernutridos, respectivamente. Aos 36 dias, metade dos animais de cada condição nutricional foram expostos ao ambiente enriquecido. A outra metade foi mantida na condição de ambiente padrão. Aos 90-120 dias de vida, foram obtidos os registros da depressão alastrante cortical. Resultados: A hipernutrição durante a lactação causou incrementos $(p<0,05)$ nos pesos corporal e cerebral. 0 Ambiente Enriquecido desacelerou a velocidade de propagação da depressão alastrante cortical independentemente do estado nutricional durante a lactação $(p<0,001)$. A desaceleração da depressão alastrante cortical no grupo nutrido/ambiente enriquecido foi de $23,8 \%$ e no grupo hipernutrido/ambiente enriquecido foi de 15\% em comparação com os grupos nutrido/ambiente padrão e hipernutrido/ambiente padrão, respectivamente. Conclusão: Nossos dados demonstram que a exposição ao ambiente enriquecido na fase juvenil da vida do rato reduz a excitabilidade cerebral, e esse efeito pode ser observado mesmo se os animais estiverem hipernutridos durante a lactação. 0 ambiente enriquecido pode ser considerado um recurso terapêutico adjuvante para modular a excitabilidade cerebral.

Palavras-chave: Depressão alastrante da atividade elétrica cortical; eletrofisiologia; ratos.

\footnotetext{
'Universidade Federal de Pernambuco, Centro de Ciências da Saúde, Departamento de Nutrição, Recife PE, Brasil;
}

¿2Universidade Federal de Pernambuco, Centro de Biociências, Departamento de Fisiologia e Farmacologia, Recife PE, Brasil.

Danielle Alves (iD) https://orcid.org/0000-0002-9598-2494; Mariana Sousa (iD) https://orcid.org/0000-0002-1384-3328; Maryane Tavares (iD) http://orcid.org/0000-0002-7149-6205; Luis Gustavo Santos (iD) http://orcid.org/0000-0003-3668-7804; Manuella Batista-de-Oliveira-Hornsby (iD https://orcid.org/0000-0003-2749-5923; Angela Amancio-dos-Santos (ID) https://orcid.org/0000-0001-7581-4090

Correspondence: Angela Amancio-dos-Santos; Departamento de Fisiologia e Farmacologia, Centro de Biociências / UFPE; Av. da Engenharia, S/N - Cidade Universitária; 50740-600 Recife PE, Brasil; E-mail:angela.asantos@yahoo.com

Support: Fundação de Amparo à Ciência e Tecnologia do Estado de Pernambuco (Edital 20/2014 - APQ-0484-2.07/15), PROPESQ/UFPE (Edital PQEmergencial 2014 - Processo no. 23076.048111/2014-22), Conselho Nacional de Desenvolvimento Científico e Tecnológico (CNPq), and Coordenação de Aperfeiçoamento de Pessoal de Nivel Superior (CAPES).

Conflict of interest: There is no conflict of interest to declare.

Received 19 December 2018; Received in final form 09 April 2019; Accepted 09 April 2019. 
Environmental enrichment (EE) is an environment that mimics a stimulating lifestyle at the laboratory level and refers to housing conditions that include the addition of inanimate objects of various textures, sizes, and shapes. These provide enhancement of sensory, cognitive and motor stimulation compared with standard living conditions ${ }^{1}$. Environmental enrichment has been found to exert beneficial effects on the morphological, cellular and molecular outcomes that underlie experience-dependent plasticity ${ }^{1,2}$; on the metabolism of the nervous system ${ }^{3}$; and on cognitive and behavioral parameters ${ }^{2}$. Moreover, EE significantly reduced seizure episodes and seizure duration in epileptic rats ${ }^{4}$. Thus, it is possible that $\mathrm{EE}$ acts to restore the excitation/inhibition balance in brain.

Despite this evidence, there are few reports concerning the putative beneficial effects of EE on brain excitability. Here, we investigated the effects of EE on cortical spreading depression (CSD) in post-weaned Wistar rats subjected to overfeeding on lactation. Cortical spreading depression is a phenomenon related to brain excitability that can be described as a remarkable reduction (depression) in the electrical activity of the brain cortex, spreading in a concentric and reversible way $^{5}$. The analyses of the velocity rate in which it spreads can be a tool for indicating brain functioning. Since its description, the mechanisms of CSD have been associated with epilepsy and other diseases that enhance brain excitability ${ }^{5}$.

The nutritional state is one of the main factors that influences brain development. Adequate nutrition is especially important during pregnancy and lactation as these phases include the so-called "brain growth spurt" when physiological process, such as neurogenesis, cell migration and differentiation, and myelination are happening ${ }^{6}$. Malnutrition in utero and during early postnatal life can cause lasting changes in many aspects of metabolic and central functions ${ }^{6}$. For example, undernutrition during lactation facilitates CSD in adult rat brains, while overnourishment impairs the propagation of the phenomenon?

A report has indicated that EE during lactation decreases CSD susceptibility and suggests that this effect is more evident in the malnourished brain, compared with the nourished brain ${ }^{8}$. Our study was the first investigation of an EE effect on CSD recorded in the brain of rats that were overfed during lactation. Clarification is still needed on how overnutrition affects brain function, especially concerning its electrophysiology, given that obesity has become a critical health problem around the world.

\section{METHODS}

The experiments were performed in accordance with the guidelines of the Ethics Committee for Animal Research of the Universidade Federal de Pernambuco (UFPE, Brazil; approval protocol no. 23076.048535/2015-78), which comply with the Principles of Laboratory Animal Care (National Institutes of Health, Bethesda, USA). Wistar rats were obtained from the nutrition department at the UFPE. They were reared in a room with a temperature of $22 \pm 2^{\circ} \mathrm{C}$ and a 12-hour light/dark cycle (lights on from 7:00 am to 7:00 pm), with free access to water and food, a commercial laboratory chow diet (Purina do Brazil Ltd., Paulinia, São Paulo, Brazil).

At birth, the rat pups were randomly distributed to be suckled in litters of either nine (group N, nourished) or three pups (group ON, overnourished) as previously described ${ }^{5,6}$. At 36 days old, half of the animals from each nutritional condition were exposed to EE. The other half was kept in the standard environment (SE). Therefore, four groups were created: N-SE ( $\mathrm{n}=10)$, N-EE ( $\mathrm{n}=12)$, ON-SE ( $\mathrm{n}=11)$, ON-EE ( $\mathrm{n}=10)$.

The EE was designed as previously published by Andin et $\mathrm{al}^{7}$. It consisted of a large acrylic cage $(100 \times 60 \times 35 \mathrm{~cm})$ containing a variety of objects, including: running wheels, toy balls, tunnels, as well as various objects of differing sizes and shapes. The objects were changed once a week. Eight rats were housed together in this cage for three hours per day for a period of four weeks. In the SE groups, 3-4 rats were housed per cage $(51 \times 35.5 \times 18.5 \mathrm{~cm})$ with only sawdust bedding and no additional objects in the cages.

At 90-120 days of life, each animal was subjected to CSD electrophysiological recording. The animals were anesthetized, intraperitoneally, with a mixture of $1000 \mathrm{mg} / \mathrm{kg}$ urethane plus $40 \mathrm{mg} / \mathrm{kg}$ alpha chloralose (both from Sigma Co., USA). A tracheal cannula was inserted to facilitate breathing. Three trephine holes (2-4 $\mathrm{mm}$ in diameter) were made on the right side of the skull, parallel to the midline. The first hole (in the frontal bone) was used to apply the stimulus that elicited CSD. The other two holes (on the parietal bone) were used to record the propagating CSD wave. During the recording sessions, rectal temperature was continuously monitored at $37 \pm 1^{\circ} \mathrm{C}$.

Cortical spreading depression was elicited at 20-minute intervals by applying, for one minute, a cotton ball (1-2 mm in diameter) soaked in a $2 \% \mathrm{KCl}$ solution (approximately $270 \mathrm{mM}$ ) to the anterior hole drilled in the frontal region. In the two parietal holes, the slow direct current potential change was recorded for four hours using a pair of $\mathrm{Ag}-\mathrm{AgCl}$ agar-Ringer electrodes (one in each hole) against a common reference electrode of the same type, placed on the nasal bones. Electrodes were connected to a digital data acquisition system (EMG Systems, São Paulo, Brazil). The velocity of CSD propagation was calculated based on the time required for a CSD wave to travel the distance between the two cortical electrodes and was expressed in $\mathrm{mm} / \mathrm{min}$. The amplitude and duration of the CSD were also calculated.

The two-way ANOVA test followed by the Holm-Sidak test was performed to assess significant differences among the experimental groups. Data were considered statistically significant if $\mathrm{p}<0.05$. All data were plotted and the statistical analysis was performed using GraphPad Prism 6.0 software (GraphPad Software Inc., La Jolla, CA, USA). 


\section{RESULTS}

Environmental enrichment did not change body and brain weights of the animals. However, ANOVA indicated that the adult animals that were previously overnourished during lactation had increased body and wet brain weights when compared with the nourished rats $(\mathrm{p}<0.05)$. There was no significant difference of dried brain weights among different experimental groups (Table 1).

Animals that were exposed to EE showed decelerated CSD propagation velocity, regardless of nutritional state during lactation $(\mathrm{p}<0.001)$. Additionally, overnourishment during lactation per se promoted a deceleration in CSD propagation velocity in comparison with the standard nutritional condition. Moreover, there was an interaction between nutritional conditions early in life and the experience with an EE. The CSD velocities of propagation (mean \pm SD) for the groups were: N-SE $3.57 \pm 0.23 \mathrm{~mm} / \mathrm{min}$; ON-SE $2.99 \pm 0.24 \mathrm{~mm} / \mathrm{min}$; N-EE $2.72 \pm 0.22 \mathrm{~mm} / \mathrm{min}$; and ON-EE $2.54 \pm 0.23 \mathrm{~mm} / \mathrm{min}$ (Figure 1). Figure 2 shows

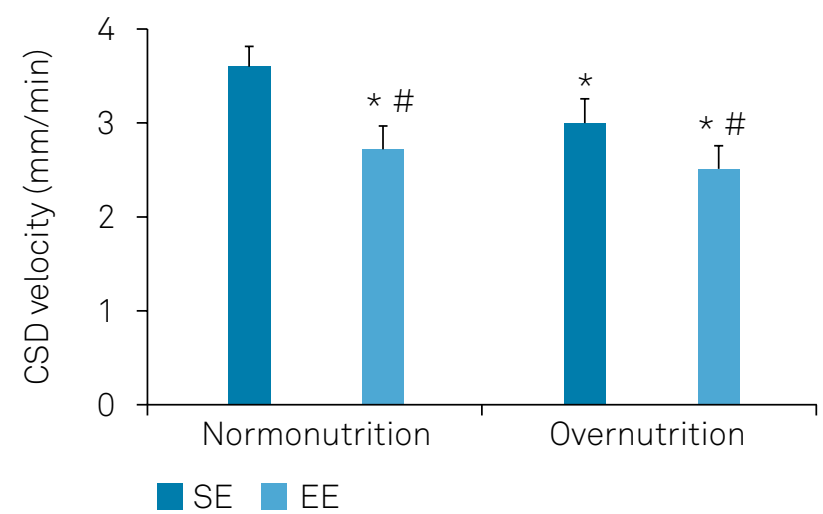

Figure 1. Cortical spreading depression (CSD) propagation velocity in adult rats that were nourished $(\mathrm{N})$ and overnourished (ON) during lactation. The animals were exposed to environmental enrichment (EE) or kept in a standard environment (SE). Data are expressed as mean \pm standard deviation and the number of animals ranged from 10 to 12 per group. *indicates statistical difference $(p<0.05)$ between $\mathrm{ON}$ and its respective $\mathrm{N}$ animals. \# represents the difference between EE and SE rats (two-way ANOVA, plus Holm-Sidak test). representative recordings of the slow direct current potential changes that accompany CSD. The wave of slow potential change can clearly express the beginning and the end of the phenomenon, and this wave is used to calculate the velocity at which CSD propagates through brain cortex. The CSD amplitudes were not changed by the different experimental conditions; CSD duration was reduced in the ON-SE group in comparison with the ON-EE group, but it did not differ among other groups (Table 2).
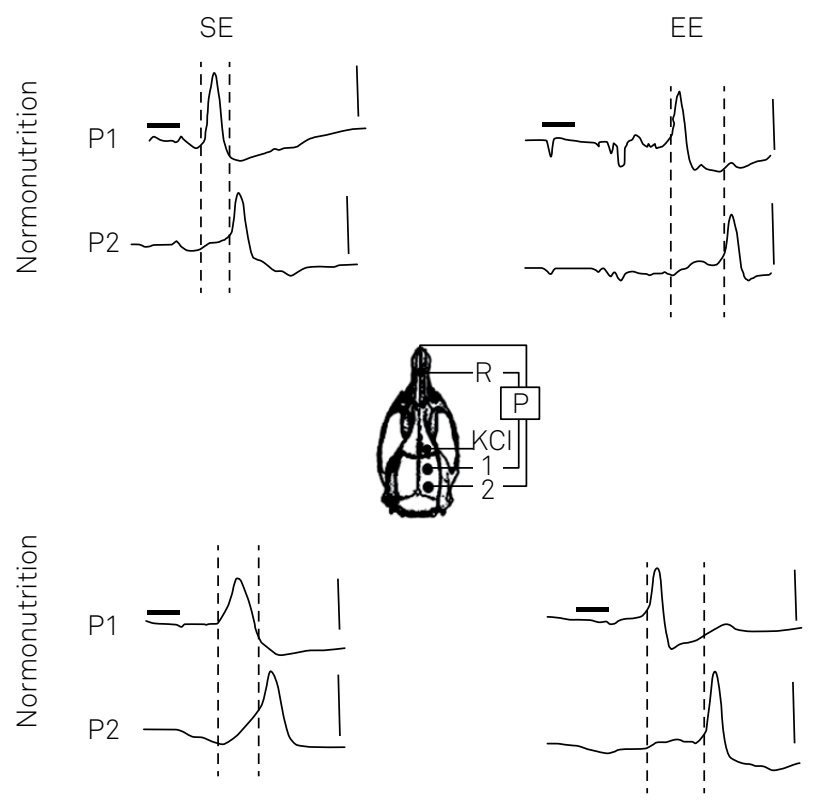

Figure 2. Electrophysiological recordings (slow potential changes, $\mathrm{P}$ ) of cortical spreading depression (CSD) in four adult rats nourished (N) or overnourished (ON) during lactation, which were exposed to environmental enrichment (EE) or kept in a standard environment (SE). The vertical solid bars at the right of the traces indicate $10 \mathrm{mV}$ (negative upwards). The horizontal bars on the traces from the recording point 1 (P1) indicate the time (1 minute) of stimulation with $2 \%$ potassium chloride $(\mathrm{KCl})$ to elicit CSD. Once elicited in the frontal cortex, CSD was recorded by the two cortical electrodes located on the parietal cortex (central skull diagram, points 1 and 2). A third electrode of the same type was placed on the nasal bones and served as a common reference $(R)$ for the recording electrodes. The vertical dashed lines indicate the latency of a CSD wave crossing the interelectrode distance.

Table 1. Body and brain weight of adult rats.

\begin{tabular}{|c|c|c|c|c|}
\hline \multirow{2}{*}{ Groups } & \multirow{2}{*}{ Body weight (g) } & \multicolumn{2}{|c|}{ Brain weight (g) } & \multirow{2}{*}{ Relative brain weight ${ }^{1}$} \\
\hline & & Wet & Dry & \\
\hline$N-S E$ & $335.11 \pm 29.27(n=10)$ & $1.7880 \pm 0.1250(n=6)$ & $0.4030 \pm 0.0340(n=6)$ & $0.5200 \pm 0.0594(n=6)$ \\
\hline$N-E E$ & $308.35 \pm 38.19(n=12)$ & $1.6550 \pm 0.1360(n=6)$ & $0.3680 \pm 0.0326(n=6)$ & $0.5020 \pm 0.0334(n=6)$ \\
\hline ON-SE & $368.08 \pm 47.61 *(n=10)$ & $1.8500 \pm 0.1620 *(n=11)$ & $0.4020 \pm 0.0424(n=11)$ & $0.5160 \pm 0.0664(n=11)$ \\
\hline ON-EE & $356.58 \pm 45.42 *(n=10)$ & $1.8250 \pm 0.1510 *(n=8)$ & $0.4050 \pm 0.0342(n=8)$ & $0.5200 \pm 0.0588(n=8)$ \\
\hline
\end{tabular}

Nourished (N) and overnourished (ON) rats during lactation were exposed to environmental enrichment (EE) or kept in a standard environment (SE). Data are expressed as mean \pm standard deviation with the number of animals in parenthesis. *indicates statistical difference ( $p<0.05)$ between the $0 \mathrm{~N}$ group and its respective $\mathrm{N}$ group (two-way ANOVA, plus Holm-Sidak test). ${ }^{1}$ Relative brain weight = wet brain weight/body weight $\times 100$ 
Table 2. Cortical spreading depression amplitude and duration.

\begin{tabular}{|c|c|c|c|c|}
\hline \multirow{2}{*}{ Groups } & \multicolumn{2}{|c|}{ Amplitude (mV) } & \multicolumn{2}{|c|}{ Duration (s) } \\
\hline & P1 & $\mathrm{P} 2$ & P1 & P2 \\
\hline N-SE & $7.73 \pm 1.77(9)$ & $6.52 \pm 2.56(8)$ & $74.73 \pm 20.43(9)$ & $61.09 \pm 22.35(9)$ \\
\hline $\mathrm{N}-\mathrm{EE}$ & $7.71 \pm 2.84(10)$ & $6.44 \pm 1.95(6)$ & $67.37 \pm 18.29(10)$ & $73.98 \pm 20.44(11)$ \\
\hline ON-SE & $8.69 \pm 3.06(10)$ & $6.43 \pm 2.72(10)$ & $64.03 \pm 23.97(10)$ & $46.38 \pm 7.21(9)$ \\
\hline ON-EE & $6.64 \pm 2.11(10)$ & $6.92 \pm 2.75(10)$ & $72.05 \pm 19.31(10)$ & $73.57 \pm 14.39(10)^{*}$ \\
\hline
\end{tabular}

Nourished (N) and overnourished (ON) rats during lactation were exposed to environmental enrichment (EE) or kept in a standard environment (SE). Data are expressed as mean \pm standard deviation with the number of animals in parenthesis. *indicates statistical difference $(p<0.05)$ between the ON-EE group and ON-SE group (two-way ANOVA, plus Holm-Sidak test). P1 and P2 = slow potential change of the two recording points on the parietal cortex.

\section{DISCUSSION}

The present study demonstrated that exposure to EE in the adolescent phase of rat development was able to reduce brain excitability as determined by the deceleration of CSD propagation. Moreover, this effect was not suppressed by overnutrition during lactation. Regarding weight parameters, overnutrition during lactation led to an increase of body weight that persisted into adulthood. Overnutrition during lactation also caused an increase in wet brain weight.

Malnutrition is related to a number of health problems as it induces malfunctions in vital organs, including the heart, pancreas, kidney, intestine and brain ${ }^{6}$. When malnutrition has occurred during the perinatal period, its adverse consequences may persist into adulthood ${ }^{6}$. The brain-related effects of overnutrition caused by enhanced food intake during early phases of development, on the other hand, are not completely understood. Our results confirm previous reports that used similar methodology ${ }^{7}$. Favorable suckling conditions resulted in increased body and brain weights when compared with the animals raised under a standard suckling condition.

On the other hand, a favorable suckling condition also reduced brain excitability, as previously described ${ }^{7}$. According to Batista-de-Oliveira et al. ${ }^{7}$, reduction of brain excitability caused by overnutrition during lactation could have been due to developmental modifications in brain structure. For instance, overnutrition could have promoted alterations on synapse formation and myelination that were dependent on the nutrition state. Data have also indicated that brain myelin content was inversely associated to CSD propagation velocity?.

Exposure to EE was shown to impair the propagation of CSD in the brain. Despite the fact that this result was similar to that of overnutrition, the two probably involved different mechanisms. Vrinda et al. ${ }^{4}$ showed that EE exerted an antagonist effect on the deflagration and duration of epileptic seizures. The underlying mechanisms of CSD seemed to be associated with epilepsy ${ }^{5}$. Thus, a reduction in EE-imposed brain excitability was expected. Moreover, EE attenuated the neuronal hyperexcitability induced by traumatic brain injury ${ }^{10}$, another condition related to $\mathrm{CSD}^{5}$.

One of the mechanisms suggested concerning the effect of EE on CSD was that it stimulated the serotonergic system. Reports have shown that EE increased serotonin levels in the brain ${ }^{11}$. Some other studies have demonstrated that brain serotonin availability also correlated inversely with CSD propagation $^{12,13}$. Thus, even though our study did not measure the serotonin brain concentration, the aforementioned evidence allowed us to infer that EE might have reduced CSD propagation velocity through the increase of serotonin availability.

It is important to point out that EE may lead to enhanced physical activity. The new environmental stimuli provided by EE continuously challenges animals to exercise more ${ }^{14}$. There is evidence that physical exercise also stimulates the activity of the serotonergic system and, as such, it exerts a role in the reduction of brain excitability. Moreover, it has been described that both EE exposure and physical exercise may act as neurogenic stimulants ${ }^{15}$. This data reinforces the hypothesis that serotonin may be one of the underlying mechanisms associated with the reduction of CSD propagation velocity as a consequence of both $\mathrm{EE}$ and physical exercise-related effects on brain function.

The role of EE as a stimulator of the brain's antioxidant activity $^{3}$ can be described as another mechanism for explaining how EE reduces CSD propagation velocity. According to Herring et al. ${ }^{14}$, cognitive and physical stimulation caused by EE mitigate pro-oxidant processes and initiate antioxidant mechanisms. In summary, these authors observed a reduction in the biomarkers of reactive oxygen and nitrogen species, a negative regulation of pro-inflammatory and pro-oxidative moderators, as well as a positive regulation of superoxide dismutase 1 and 2. Free radicals have been described as mediators of the neuronal excitability that is necessary to elicit $\mathrm{CSD}^{16}$. Moreover, the occurrence of CSD phenomena induces the production of reactive oxygen species in the rat brain. Therefore, it is reasonable to suggest that an increased antioxidant defense caused by EE in the nervous system could serve as a barrier for the elicitation and/or propagation of the CSD phenomenon.

Finally, the present study questioned whether manipulating nutritional intake would change the effects of $\mathrm{EE}$ on CSD propagation. The deceleration of CSD propagation by EE was observed regardless of overnutrition during lactation. Previous studies have reported that the nutritional conditions during lactation can influence the action of certain medicines and biological compounds. For instance, the effects of diazepam and glucose on CSD were reduced if rats 
were malnourished during lactation ${ }^{17}$. However, pilocarpinerelated cholinergic effects on CSD were potentiated if malnutrition occurred during lactation ${ }^{18}$. We believe EE represents a beneficial strategy for improving brain function, independent of the nutritional state in the beginning of life.

In conclusion, this study demonstrated that exposure to EE in the juvenile phase of a rat's life reduced brain excitability, and this effect was observed even if the animals were previously overnourished during lactation. Environmental enrichment is a simple, accessible and low-cost approach that could be considered as an adjuvant therapeutic resource for the treatment of epilepsy and migraine, diseases known to be treated by different techniques that can modulate brain excitability.

\section{ACKNOWLEDGMENTS}

The authors thank Jessica McGlone-White, Master of Science in Special Education, and Manuella Batista-deOliveira Hornsby Ph.D. for their suggestions and review of the English version of the text.

\section{References}

1. Nithianantharajah J, Hannan AJ. Enriched environments, experience-dependent plasticity and disorders of the nervous system. Nat Rev Neurosci. 2006 Sep;7(9):697-709. https://doi.org/10.1038/nrn1970

2. Ohline SM, Abraham WC. Environmental enrichment effects on synaptic and cellular physiology of hippocampal neurons. Neuropharmacology. 2019 Feb;145(Part A):3-12. https://doi.org/10.1016/j.neuropharm.2018.04.007

3. Mármol F, Sánchez J, Torres MN, Chamizo VD. Environmental enrichment in the absence of wheel running produces beneficial behavioural and anti-oxidative effects in rats. Behav Processes. 2017 Nov;144:66-71. https://doi.org/10.1016/j.beproc.2017.09.009

4. Vrinda M, Sasidharan A, Aparna S, Srikumar BN, Kutty BM, Shankaranarayana Rao BS. Enriched environment attenuates behavioral seizures and depression in chronic temporal lobe epilepsy. Epilepsia. 2017 Jul;58(7):1148-58. https://doi.org/10.1111/epi.13767

5. Kramer DR, Fujii T, Ohiorhenuan I, Liu CY. Cortical spreading depolarization: Pathophysiology, implications, and future directions. J Clin Neurosci. 2016 Feb;24:22-7. https://doi.org/10.1016/j.jocn.2015.08.004

6. Morgane PJ, Austin-LaFrance R, Bronzino J, Tonkiss J, DíazCintra S, Cintra L, et al. Prenatal malnutrition and development of the brain. Neurosci Biobehav Rev. 1993;17(1):91-128. https://doi.org/10.1016/S0149-7634(05)80234-9

7. Batista-de-Oliveira M, Monte-Silva-Machado KK, Paiva AK, Lima H, Fregni F, Guedes RC. Favorable and unfavorable lactation modulates the effects of electrical stimulation on brain excitability: a spreading depression study in adult rats. Life Sci. 2012 Sep;91(9-10):306-11. https://doi.org/10.1016/j.lfs.2012.07.011

8. Guedes RC, Monteiro JS, Teodósio NR. Malnutrition and brain function: experimental studies using the phenomenon of cortical spreading depression. Rev Bras Biol. 1996 Dec;56 Su 1(Pt 2):293-301.

9. Merkler D, Klinker F, Jürgens T, Glaser R, Paulus W, Brinkmann $\mathrm{BG}$, et al. Propagation of spreading depression inversely correlates with cortical myelin content. Ann Neurol. 2009 Sep;66(3):355-65. https://doi.org/10.1002/ana.21746

10. Alwis DS, Yan EB, Johnstone V, Carron S, Hellewell S, MorgantiKossmann MC, et al. Environmental Enrichment Attenuates Traumatic Brain Injury: Induced Neuronal Hyperexcitability in Supragranular Layers of Sensory Cortex. J Neurotrauma. 2016 Jun;33(11):1084-101. https://doi.org/10.1089/neu.2014.3774

11. Ragu Varman D, Rajan KE. Environmental enrichment reduces anxiety by differentially activating serotonergic and neuropeptide (NPY) ergic system in Indian field mouse (Mus booduga): an animal model post-traumatic stress disorder. PLoS One. 2015 May;10(5):e0127945. https://doi.org/10.1371/journal.pone.0127945

12. Amancio-dos-Santos A, Maia LM, Germano PC, Negrão YD, Guedes RC. Tianeptine facilitates spreading depression in wellnourished and early-malnourished adult rats. Eur J Pharmacol. 2013 Apr;706(1-3):70-5. https://doi.org/10.1016/j.ejphar.2013.02.047

13. Guedes RC, Araújo MD, Verçosa TC, Bion FM, de Sá AL, Pereira A Jr, et al. Evidence of an inverse correlation between serotonergic activity and spreading depression propagation in the rat cortex. Brain Res. 2017 Oct;1672:29-34. https://doi.org/10.1016/j.brainres.2017.07.011

14. Herring A, Blome M. Ambrée O, Sachser N, Paulus W, Keyvani K. Reduction of cerebral oxidative stress following enriched environment in mice Alzheimerlike pathology. Brain Pathol. 2010;20(1):166-75. https://doi.org/10.1111/j.1750-3639.2008.00257.x PMID:19134003

15. Klein C, Schreyer S, Kohrs FE, Elhamoury P, Pfeffer A, Munder T, et al. Stimulation of adult hippocampal neurogenesis by physical exercise and enriched environment is disturbed in a CADASIL mouse model. Sci Rep. 2017 Mar;7(1):45372. https://doi.org/10.1038/srep45372

16. Malkov A, Ivanov Al, Popova I, Mukhtarov M, Gubkina O, Waseem T, et al. Reactive oxygen species initiate a metabolic collapse in hippocampal slices: potential trigger of cortical spreading depression. J Cereb Blood Flow Metab. 2014 Sep;34(9):1540-9. https://doi.org/10.1038/jcbfm.2014.121

17. Costa-Cruz RR, Guedes RC. Cortical spreading depression during streptozotocin-induced hyperglycaemia in nutritionally normal and early-malnourished rats. Neurosci Lett. 2001 May;303(3):177-80. https://doi.org/10.1016/S0304-3940(01)01736-0

18. Vasconcelos CA, Oliveira JA, Costa LAO, Guedes RC. Malnutrition and REM-sleep deprivation modulate in rats the impairment of spreading depression by a single sub-convulsing dose of pilocarpine. Nutr Neurosci. 2004 Jun;7(3):163-70. https://doi.org/10.1080/10284150412331281031 